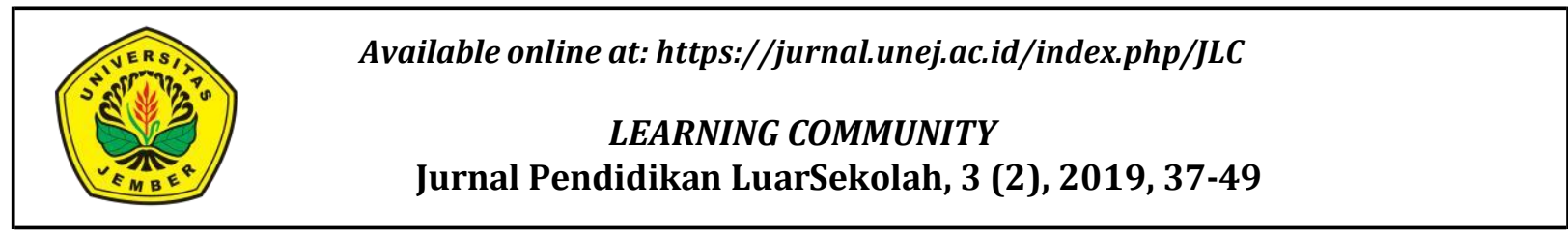

\title{
Manajemen Program Kursus Tata Rias Pengantin Solo Putri Di Lembaga Kursus Dan Pelatihan (LKP) Widya Semarang
}

\author{
Fajar Nugraheni, Liliek Desmawati \\ Jurusan Pendidikan Luar Sekolah, Fakultas Ilmu Pendidikan, Universitas Negeri Semarang \\ Gedung A2 Kampus Sekaran Gunungpati Telp. 8508019 Semarang 50229 \\ Email : fajar.nugraheni168@gmail.com, liliek@unnes.ac.id.
}

\begin{abstract}
Abstrak
Penelitian ini bertujuan mendeskripsikan proses perencanaan, pengorganisasian, pelaksanaan, pengawasan, dan evaluasi, serta faktor-faktor yang memengaruhi proses manajemen program kursus Tata Rias Pengantin Solo Putri di LKP Widya Semarang. Subjek penelitian, yaitu satu pengelola, satu instruktur, dan empat peserta didik. Teknik pengumpulan data melalui observasi, wawancara, dan dokumentasi. Keabsahan data menggunakan triangulasi sumber dan teknik. Teknik analisis data melalui reduksi data, penyajian data, dan penarikan kesimpulan. Hasil penelitian diperoleh bahwa proses manajemen diawali dengan perencanaan yang meliputi penyusunan tujuan, pengadaan sarana dan prasarana, perencanaan biaya, perekrutan instruktur, dan peserta didik. Selanjutnya, pengorganisasian dilakukan terhadap SDM lembaga dan instruktur, serta jalinan kerja sama. Pelaksanaan berjalan sesuai yang direncanakan dimana waktu dan tempat bersifat fleksibel, serta kesesuaian materi, metode, dan media sudah tepat. Pengawasan dilakukan secara eksternal dan internal. Evaluasi meliputi pengukuran keberhasilan program dan pembinaan lulusan. Faktor-faktor yang memengaruhi terdiri dari faktor pendukung dan penghambat.
\end{abstract}

Kata kunci: Manajemen Program, Kursus Tata Rias, Pengantin Solo Putri

\section{Management Of The Solo Putri Bridal Make-Up Course Program At Widya Course And Training Institute (LKP) Semarang}

\begin{abstract}
This research aim is to describe the process of planning, organizing, actuating, monitoring, and evaluating, also the factors that influence the management process of the Solo Putri Bridal Make-up program in LKP Widya Semarang. Research subjects, are one manager, one instructor, and four students. Data collection techniques through observation, interviews, and documentation. The validity of the data uses triangulation of sources and techniques. Data analysis techniques through data reduction, data presentation, and conclusion drawing. The research results show that the management process begins with planning which includes the preparation of objectives, procurement of facilities and infrastructure, cost planning, recruitment of instructors and students. Furthermore, organizing is carried out on human resources institutions and instructors, also cooperation relationship. Implementation runs according to plan where time and place are flexible, and the suitability of the material, method, and media is appropriate. Controlling is carried out externally and internally. Evaluation includes measuring the success of the program and alumnus guidance. The influencing factors consist of supporting and inhibiting factors.
\end{abstract}

Keywords: Program Management, Make-up Course, Solo Putri Bride 


\section{Learning Community: Jurnal Pendidikan Luar Sekolah, 3 (2), September 2019 - 38}

Fajar Nugraheni

\section{PENDAHULUAN}

Perkembangan zaman menuntut masyarakat untuk berkompeten agar mampu bersaing dalam pasar kerja global. Pendidikan nonformal melalui program kursus mengupayakan untuk menyiapkan sumber daya manusia yang berkompeten tersebut dengan memberikan bekal keterampilan praktis yang terkait dengan kebutuhan pasar kerja, peluang usaha, potensi ekonomi atau industri yang ada di masyarakat. Selama ini, program kursus bukanlah hal yang asing bagi masyarakat, karena telah cukup berkembang dan diminati. Kursus diselenggarakan bagi masyarakat yang memerlukan bekal pengetahuan, keterampilan, kecakapan hidup, dan sikap untuk mengembangkan diri, mengembangkan profesi, bekerja, usaha mandiri, dan/atau melanjutkan pendidikan ke jenjang yang lebih tinggi. Kursus juga merupakan bentuk pendidikan untuk mengembangkan kemampuan peserta didik dengan penekanan pada penguasaan keterampilan.

Pendidikan kursus terbuka bagi siapapun, baik mereka yang sedang mengenyam pendidikan formal, yang sudah lulus namun belum bekerja, dan yang sedang bekerja. Melalui kursus, seseorang dapat memelajari keterampilan baru maupun mengasah keterampilan yang sudah dimiliki. Hal ini didukung dengan adanya sistem level dalam pendidikan kursus, dimana semakin tinggi level, maka keterampilan yang dipelajari akan semakin kompleks. Dengan demikian, seseorang yang sudah memiliki keterampilan dapat lebih menguasainya dengan mengambil level selanjutnya agar dia semakin mahir dalam keterampilannya tersebut.

Kursus dapat diselenggarakan oleh satuan pendidikan nonformal, yaitu Lembaga Kursus dan Pelatihan (LKP), Pusat Kegiatan Belajar Masyarakat (PKBM), Sanggar Kegiatan Belajar (SKB), penyelenggaraan lembaga pemerintah desa, dan lembaga lain yang sejenis. Penyelenggaraan kursus harus dapat dipertanggungjawabkan kepada masyarakat dan negara sebagai bagian dari akuntabilitas publik. Hal ini berdasarkan Undang-undang Nomor 20 Tahun 2003 tentang Sistem Pendidikan Nasional pasal 62 yang mengamanatkan bahwa setiap satuan pendidikan formal dan nonformal wajib memperoleh izin Pemerintah atau Pemerintah Daerah. Oleh karena itu, penyelenggara perlu mengurus perizinan terlebih dahulu yang diterbitkan oleh Bupati/Walikota atau Kepala Dinas Pendidikan Kabupaten/Kota atas nama Bupati/Walikota, sebagai bentuk pemberian legalitas atas penyelenggaraan kursus di wilayah kerjanya. Dalam mengurus perizinan ini, penyelenggara wajib memenuhi persyaratan yang meliputi program dan isi pendidikan dalam bentuk struktur kurikulum; jumlah dan kualifikasi pendidik dan tenaga kependidikan; sarana dan prasarana yang memadai baik jumlah dan kualitasnya; pembiayaan yang diuraikan dalam komponen biaya investasi dan biaya personal (yang harus dikeluarkan oleh peserta didik); rencana sistem evaluasi dan sertifikasi; rencana manajemen dan proses pendidikan dalam bentuk uraian manajemen pengendalian mutu, serta persyaratan lain mengenai perizinan kursus yang bersifat administrasi ditentukan oleh Pemerintah Daerah setempat. (http://www.infokursus.net/perijinan.php).

Sebanyak 17.776 Lembaga Kursus dan Pelatihan (LKP) yang ada di Indonesia, baru $8 \%$ atau sekitar 1.200-an saja yang telah mendapatkan akreditasi dari pemerintah. Hal tersebut disampaikan oleh Direktur Pembinaan Kursus dan Pelatihan Dirjen Pendidikan Anak Usia Dini, Non formal dan Informal (PAUDNI), Kemendikbud, Dr. Wartanto kepada pers di Solo, Jawa Tengah pada tahun 2015. Lebih lanjut Wartanto mengatakan, LKP memiliki peran yang cukup besar dalam menyerap tenaga kerja yaitu sebanyak $78 \%$ diterima di dunia kerja, $12 \%$ berwirausaha, dan sisanya tidak terdeteksi.(http://scholae.co/web/read/722/s aatnya. lembaga. kursus.berbenah).

Perkembangan keberadaan kursus memang sangat luar biasa, berdasarkan data dari Direktorat Pembinanaan Kursus dan Pelatihan bahwa jumlah LKP selalu meningkat dari tahun ke tahun. Fenomena peningkatan jumlah ini sayangnya belum diiringi dengan peningkatan mutu kursus yang ditandai penyediaan sarana prasarana yang memadai, tenaga pendidik dan kependidikan yang kompeten, kurikulum yang sesuai dengan perkembangangan zaman dan lain-lain yang tidak sesuai dengan standar minimal yang telah ditentukan. Berbagai upaya telah dilakukan pemerintah dalam hal ini Direktorat Pembinaan Kursus dan Pelatihan Ditjen PAUDNI untuk meningkatkan mutu lembaga kursus, mulai dari penguatan sarana prasarana, pelatihan tenaga pendidik dan 
tenaga kependidikan, program-program subsidi kursus, dengan harapan bahwa pengelolaan kursus dapat lebih bermutu sehingga lulusan yang dihasilkan dapat berkompetisi di dunia usaha dan dunia industri.

Tidak semua pihak menaati peraturan yang telah dibuat. Meskipun pemerintah telah memberlakukan peraturan tentang kewajiban perizinan bagi penyelenggaraan lembaga kursus, namun masih ditemukan oknumoknum yang justru tidak menghiraukannya. Dilansir oleh media online Tribunpontianak.co.id, Direktur Pembinaan Kursus dan Pelatihan Kementerian Pendidikan dan Kebudayaan RI, Dr. Yusuf Muhyiddin pada tanggal 7 Maret 2018 menyatakan bahwa masih terdapat lembaga kursus yang ilegal di Indonesia. Mereka beroperasi, namun tidak mengurus perizinan terlebih dahulu sesuai yang diprosedurkan. Mereka tidak berhak mendapatkan bantuan dari pemerintah yang hanya diperuntukkan bagi lembaga legal dan prioritas pada lembaga yang terakreditasi. (http://pontianak.tribunnews.com/amp/2018 /03/07/kemendikbud-sebut-masih-ada lembaga-kursus-ilegal-di-indonesia).

Hal yang sama juga dikeluhkan oleh pihak Kecamatan Kelapa Dua, Kabupaten Tangerang karena banyak lembaga kursus yang beroperasi di wilayah mereka tanpa mengurus perizinan secara menyeluruh. Kepala Seksi Kesejahteraan Sosial Kecamatan Kelapa Dua, Ahmad Gaos menjelaskan bahwa lembaga kursus yang ingin beroperasi di wilayah Kecamatan Kelapa Dua merasa cukup dengan hanya mengurus Surat Keterangan Domisili Usaha (SKDU). Padahal, SKDU baru salah satu bagian dari rangkaian tahapan perizinan. Jika diperhatikan, biasanya yang tidak mengurus izin sampai benar-benar selesai ini adalah lembaga kursus yang beranggapan sudah memiliki nama yang besar dan populer di masyarakat. (https://megapolitan.kompas.com/read/2015 /08/07/19515251/Banyak.Lembaga.

Kursus.yang.Malas.Urus.Izin.Operasional).

Akibat dari adanya pelanggaran di atas, pemerintah pun tidak dapat melakukan pengawasan dan penjaminan terhadap kualitas lembaga tersebut. Padahal kualitas lembaga yang juga berdampak pada kualitas lulusan peserta didik di lembaga tersebut menjadi tanggung jawab bersama antara pemerintah, akademisi, dunia usaha dan dunia industri serta masyarakat. Alhasil, dikhawatirkan apa yang menjadi tujuan utama diselenggarakan program kursus tidak tercapai secara maksimal. Sikap para penyelenggara lembaga kursus yang demikian menggambarkan bahwa keadaan proses manajemen di dalamnya dijalankan dengan kurang baik. Dimana pada proses manajemen tersebut terdapat proses perencanaan, pengorganisasian, pelaksanaan, pengawasan, hingga evaluasi yang seharusnya menjadikan lembaga beroperasi secara terstruktur dan sistematis mengikuti pedoman yang diberlakukan.

Selain terjadinya pelanggaran tidak diurusnya perizinan oleh penyelenggara lembaga kursus, buruknya proses manajemen juga dapat membuat LKP yang diselenggarakannya tidak bertahan lama. Semakin menjamurnya LKP di tengah masyarakat, membuat penyelenggara harus mampu bersaing untuk saling memertahankan eksistensinya. Hal ini pun sangat memerlukan proses manajemen yang baik sebagai strateginya agar lembaga yang dimiliki tetap mendapatkan tempat di hati masyarakat. Tidak heran, bagi mereka yang tidak dapat melakukan manajemen dengan baik, maka cepat atau lambat lembaganya tidak lagi beroperasi atau mati.

Kualitas program kursus yang menjadi penentu kuat lemahnya suatu LKP perlu menjadi perhatian pokok. Hal tersebut mendapatkan pengaruh dari proses manajemen yang dilakukan. Lembaga kursus yang ingin berkembang, harus didukung oleh manajemen yang baik pula. Manajemen program kursus dimaksudkan untuk membantu para pengelola LKP dalam meningkatkan kualitas sehingga mampu menghasilkan output pendidikan kursus dan pelatihan yang berkompeten dan dapat memenuhi kebutuhan serta syarat untuk mencari kerja atau membangun usaha. Manajemen program yang baik setidaknya mencakup perencanaan yang matang, proses pelaksanaan, hingga evaluasi untuk mengetahui kekurangan dan kelebihan program. Selain itu, juga perlu adanya proses pengorganisasian, agar terdapat pembagian tugas dan fungsi secara jelas, serta proses pengawasan dimana data yang diperoleh dapat digunakan dalam proses evaluasi.

Pada era sekarang ini, lembagalembaga kursus berkembang dengan berbagai keterampilan yang dikursuskan. Keterampilan tersebut biasanya merupakan hal yang dekat 
dengan kehidupan, sehingga dibutuhkan oleh masyarakat. Tata Rias Pengantin adalah salah satu keterampilan yang dikursuskan disamping kursus menjahit, komputer, bahasa asing dan bidang lainnya yang sudah umum di dunia pendidikan kursus. Seperti kita ketahui, pernikahan merupakan suatu peristiwa yang tidak akan pernah hilang selama masih ada kehidupan di dunia ini. Setiap manusia tentu memimpikan untuk membangun rumah tangga suatu saat nanti. Proses untuk menuju hal tersebut adalah dengan melakukan pernikahan secara sah baik menurut agama ataupun negara. Dilihat dari sisi budaya, pernikahan pun memiliki nilai-nilai tradisi tersendiri sesuai adat yang berkembang di tiap-tiap daerah. Oleh karena itu, upacara pernikahan menjadi hal sakral bagi masyarakat yang masih menjunjung tinggi nilai tradisi kebudayaan. Kesakralan ini dapat digambarkan pada rangkaian ritual upacara, tata rias, dan pakaian yang dikenakan kedua mempelai pengantin yang masing-masing memiliki makna tersendiri.

Lembaga Kursus dan Pelatihan (LKP) Widya adalah lembaga yang mengadakan kursus Tata Rias Pengantin di Kota Semarang. LKP yang dipimpin oleh Ibu Sri Medali Hendry Hastuti, S.Sos. atau lebih dikenal Ibu Medali ini berada di Jalan Kintelan Baru No. 24, Kelurahan Bendungan, Kecamatan Gajahmungkur, Kota Semarang, Jawa Tengah. Program kursus yang diselenggarakan, yaitu Tata Rias Pengantin, Salon Kecantikan, Hantaran, dan Spa Terapis.

Berbagai macam gaya Tata Rias Pengantin tradisional menjadi fokus LKP Widya untuk mendidik perias pengantin yang turut mempertahankan warisan budaya bangsa, seperti Solo Putri, Solo Basahan, Jogja Putri, dan Paes Ageng. Tata Rias Pengantins Solo Putri merupakan dasar yang wajib dikuasai oleh perias sebelum memelajari gaya lainnya. Tata Rias Pengantin Solo Putri ini juga masih cukup banyak dipakai oleh pengantin, sehingga keterampilan perias-perias tradisional masih banyak dibutuhkan. Sejauh ini, opini publik terhadap para lulusan LKP Widya cukup baik dan tidak diragukan kemampuannya. Tidak jarang pihak-pihak yang menggunakan jasa mereka dalam keperluannya.

LKP Widya dipilih sebagai lokasi penelitian, karena memiliki beberapa keunggulan dibandingkan lembaga kursus lainnya. Pertama, perekrutan peserta didik dapat dilakukan melalui kerja sama dengan menjadi instruktur dalam pelatihan yang diadakan oleh dinas. Selain itu, melalui kerja sama seperti ini, instruktur memeroleh pemasukan dana yang sebagian juga digunakan untuk pengelolaan lembaga. Sumber pemasukan dana lembaga lainnya berasal dari biaya yang dibayarkan oleh peserta didik. Dalam pembiayaan ini, terdapat subsidi ataupun promo potongan harga yang diberikan lembaga, ditambah kemudahan untuk dapat membayarnya secara diangsur. Kebijakan seperti ini cukup membantu meringankan peserta didik, karena dapat dikatakan bahwa biaya yang dikeluarkan lebih rendah dibandingkan mengikuti kursus di lembaga lain.

Waktu pelaksanaan program pun fleksibel, sehingga peserta didik masih tetap dapat melakukan aktivitas lainnya, seperti bekerja dan kuliah. Kemudian, dari segi instruktur juga seperti teman sendiri, ramah, dan membuat pelaksanaan program kursus menjadi menyenangkan. Para peserta didik merasa seperti bagian dari keluarga dengan pengelola LKP dan instruktur. Satu keunggulan lagi yang membedakan LKP Widya dengan lembaga kursus lainnya adalah terdapat pembinaan berkelanjutan bagi lulusan peserta didik. Meskipun telah menjadi alumni, lembaga tetap mengadakan pertemuan rutin sebagai upaya pembinaan dengan memelajari materimateri tertentu yang masih berkaitan dengan bekal sebagai perias pengantin. Pembinaan juga dapat menjadi sarana menjalin networking, sehingga seringkali mereka pun menjadi rekan dalam bekerja.

\section{METODE}

Peneliti menggunakan penelitian kualitatif. Hal ini dikarenakan permasalahan yang dibahas akan menghasilkan data yang berupa kata-kata baik lisan maupun tertulis, berupa gambaran dan bukan angka-angka. Dengan pendekatan ini diharapkan temuantemuan empiris dapat dideskripsikan secara lebih rinci, lebih jelas dan lebih akurat, terutama berbagai hal yang berkaitan dengan pelaksanaan kegiatan yang dilakukan sebagai upaya mendeskripsikan mengenai bagaimana manajemen program kursus Tata Rias Pengantin Solo Putri di Lembaga Kursus dan Pelatihan (LKP) Widya yang beralamatkan di Jalan Kintelan Baru No. 24, Kelurahan Bendungan, Kecamatan Gajahmungkur, Kota Semarang, Jawa Tengah. 


\section{Learning Community: Jurnal Pendidikan Luar Sekolah, 3 (2), September 2019 - 41}

Fajar Nugraheni

Subjek dalam penelitian ini adalah satu orang pengelola dan satu orang instruktur program kursus Tata Rias Pengantin Solo Putri LKP Widya. Sedangkan, informan dalam penelitian ini,yaitu empat orang peserta didik program kursus Tata Rias Pengantin Solo Putri di LKP Widya. Fokus penelitian menyatakan pokok persoalan yang menjadi pusat perhatian dalam penelitian. Adapun yang menjadi fokus penelitian ini adalah proses perencanaan, pengorganisasian, pelaksanaan, pengawasan, dan evaluasi program kursus Tata Rias Pengantin Solo Putri di LKP Widya Semarang, serta faktor-faktor yang memengaruhi dalam proses manajemen tersebut.

Selanjutnya, sumber data dalam penelitian ini dibagi menjadi tiga, yaitu (1) Person yaitu dari pengelola, instruktur, dan peserta didik.. (2) Place yaitu mengenai gambaran umum lembaga, sarana dan prasarana, proses pelaksanaan program kursus, dan data-data yang digunakan dalam proses evaluasi. (3) Paper yaitu terdiri dari dokumen tertulis dan foto-foto.

Teknik pengumpulan data melalui observasi, wawancara, dan dokumentasi. Keabsahan data yang digunakan, yaitu triangulasi sumber dan teknik. Triangulasi sumber untuk menguji kredibilitas data dilakukan dengan cara mengecek data yang telah diperoleh melalui beberapa sumber, yaitu pengelola, instruktur, dan peserta didik. Data dari berbagai sumber dideskripsikan, dikategorisasikan, mana pandangan yang sama, yang berbeda, dan mana spesifik dari beberapa sumber tersebut. Triangulasi teknik untuk menguji kredibilitas data dilakukan dengan cara mengecek data kepada sumber yang sama dengan teknik yang berbeda, yaitu observasi, wawancara, dan dokumentasi. Analisis data dilakukan sebelum dan selama di lapangan, melalui reduksi data, penyajian data dan verifikasi atau penarikan kesimpulan.

\section{HASIL DAN PEMBAHASAN}

Berdasarkan penelitian yang telah dilakukan terkait manajemen program kursus Tata Rias Pengantin Solo Putri di LKP Widya Semarang, didapatkan hasil penelitian bahwa proses manajemen yang mencakup: (1) proses perencanaan, (2) proses pengorganisasian, (3) proses pelaksanaan, (4) proses pengawasan, (5) proses evaluasi, dan (6) faktor pendukung dan penghambat dalam proses manajemen program kursus Tata Rias Pengantin Solo Putri di LKP Widya Semarang, adalah sebagai berikut:

Perencanaan merupakan proses yang menjadi dasar dalam merancang sebuah program. Proses perencanaan diawali dengan penyusunan tujuan program yang berdasarkan identifikasi kebutuhan yang telah dilakukan. Tujuan dari program kursus Tata Rias Pengantin Solo Putri di LKP Widya adalah untuk memberikan pengetahuan dan keterampilan Tata Rias Pengantin Solo Putri yang sesuai dengan tradisi budaya, sehingga para peserta didik dapat menerapkan ilmunya sebagai ladang memeroleh penghasilan di kemudian hari.

Setelah menentukan tujuan program, pengelola merencanakan dan menyiapkan sarana dan prasarana yang akan digunakan dalam proses pelaksanaan program nantinya. Pengadaan sarana dan prasarana dilakukan untuk mendukung keberhasilan pencapaian tujuan program kursus, sehingga diupayakan ketersediannya memadai. Pengadaan sarana dan prasarana serta untuk kebutuhan program lainnya tentu memerlukan biaya. Oleh karena itu, perencanaan selanjutnya adalah mengenai biaya. Pihak lembaga memerlukan biaya untuk mendukung kelancaran proses program. Perencanaan biaya dalam program ini berasal dari berbagai sumber, yaitu kerja sama dengan mitra, unit usaha tata rias dan dana dari siswa yang dapat dibayarkan secara berangsurangsur.

Kualitas instruktur dalam mendidik akan memengaruhi kualitas peserta didik pula. Hal ini dikarenakan seorang instruktur akan berperan penting dalam menentukan bagaimana proses program kursus dan hasilnya nanti pada peserta didik. Oleh karena itu, perekrutan instruktur menyesuaikan standard yang berlaku sebagai seorang instruktur dengan syarat utama memiliki keahlian yang kompeten di bidang Tata Rias Pengantin dibuktikan dengan dimilikinya sertifikat dari Lembaga Sertifikasi Kompetensi (LSK). Selain dari dalam lembaga, pada keadaan tertentu juga didatangkan instruktur dari luar lembaga.

Peserta didik merupakan bahan utama yang akan diolah dalam program kursus di LKP. Perekrutan peserta didik dilakukan dengan membagikan brosur-brosur sebagai bentuk promosi dan melalui perekrutan peserta pelatihan yang telah diselenggarakan oleh dinas-dinas atau mitra kerja, kemudian memenuhi persyaratan pendaftaran secara 


\section{Learning Community: Jurnal Pendidikan Luar Sekolah, 3 (2), September 2019 - 42}

Fajar Nugraheni

administrasi. Peserta didik yang mengikuti kursus tidak dibatasi menurut latar belakangnya.

Proses pengorganisasian merupakan kegiatan utama dalam manajemen program. Proses pengorganisasian program kursus Tata Rias Pengantin Solo Putri di LKP Widya meliputi pengorganisasian sumber daya manusia lembaga yang diawali dengan pembentukan struktur organisasi. Selanjutnya, dilakukan pembagian tugas sesuai dengan kemampuan masing-masing jabatan dalam struktur organisasi ini. Pembagian tugas ini dimaksudkan agar proses manajemen program kursus ini dapat berjalan secara efektif dan efisien. Selain itu, pengorganisasian juga dilakukan pada instruktur. Pengorganisasian instruktur meliputi pembagian tugas antar instruktur dilakukan menyesuaikan materi dan keadaan, dimana asisten instruktur dapat berperan sebagai pendamping ataupun pengganti instruktur utama.

Keberhasilan pelaksanaan program kursus tidak hanya berasal dari internal lembaga, namun juga melibatkan berbaga pihak dari luar. Keterlibatan phak luar ini dilakukan dengan adanya jalinan kerja sama yang dapat mendukung lembaga dalam pencapaian tujuan program ini. Oleh karena itu, dalam proses pengorganisasian selanjutnya adalah terkait jalinan kerja sama lembaga dengan pihak luar. Jalinan kerja sama LKP Widya dilakukan bersama berbagai pihak baik pemerintah maupun swasta berupa pemberian dukungan kegiatan, sebagai narasumber kegiatan, dan permintaan jasa merias. hak yang menjalin kerja sama dengan LKP Widya antara lain Disnaker, Disdikbud, DP3A, GOW, Amira, dan Inez.

Pelaksanaan merupakan proses penerapan dari apa yang telah disusun dalam proses perencanaan sebuah program. Mengingat latar belakang peserta didik yang beraneka ragam, jadwal program kursus di LKP Widya dilaksanakan secara fleksibel. Penyusunan jadwal disesuaikan dengan kesibukan masing-masing peserta didik dan instruktur. Selanjutnya, pengelola juga menyiapkan tempat untuk melaksanakan program kursus di bangunan LKP Widya sendiri. Sesekali lembaga menyewa tempat di luar gedung LKP untuk kegiatan tertentu, misalnya di hotel dengan mengundang pembicara.
Pada proses pelaksanaan program kursus Tata Rias Pengantin Solo Putri di LKP Widya ini peserta didik diberikan materi oleh instruktur. Materi yang diberikan sejalan dengan apa yang menjadi tujuan program. Materi yang diajarkan pada program kursus Tata Rias Pengantin Solo Putri di LKP Widya disesuaikan dengan kompetensi yang diujikan secara nasional. Materi mencakup kemampuan teori adat, praktik keterampilan, dan praktik merias dari wajah, rambut, hingga busana, serta motivasi agar menjadi perias pengantin yang profesional kelak.

\section{Metode instruktur dalam proses} pelaksanaan program kursus akan berpengaruh terhadap materi yang dapat terserap oleh peserta didik. Peneliti mengamati bahwa program kursus didominasi dengan praktik dan sedikit teori. Oleh karena itu, metode yang digunakan adalah gabungan antara metode ceramah dan demonstrasi. Kesuaian metode yang diterapkan dalam proses pelaksanaan program sudah tepat dan mudah dipahami oleh peserta didik.

Proses pelaksanaan program kursus juga memanfaatkan media untuk membantu peserta didik dalam memahami materi yang diberikan oleh instruktur. Kesesuaian media yang digunakan dalam proses pelaksanaan program sudah tepat dan mendukung peserta didik untuk mempraktikkan materi, yaitu patung, perlengkapan keterampilan, dan seorang model untuk dirias, serta papan tulis dan LCD juga digunakan saat program dilaksanakan di luar LKP.

Proses pengawasan merupakan upaya memantau orang-orang yang terlibat dalam proses pelaksanaan program dan memastikan tugas dan fungsinya dijalankan sesuai dengan tujuan yang telah direncanakan. Melalui proses pengawasan ini, segala kesalahan yang ditemukan dalam proses pelaksanaan dapat segera diperbaiki. Proses pengawasan program dilakukan dari pihak luar maupun dalam lembaga sendiri. Pengawasan dari pihak luar dilakukan oleh dinas. LKP Widya secara rutin memberikan laporan kegiatan kepada dinas setiap tiga bulan sekali. Kemudian, pengawasan dari dalam lembaga dilakukan oleh pengelola dan instruktur terhadap kinerja instruktur dan perkembangan peserta didik saat proses pelaksanaan program berlangsung.

Evaluasi merupakan proses yang terakhir dalam manajemen, yaitu mengukur kesesuaian antara pelaksanaan dengan tujuan yang telah direncanakan. Evaluasi program ini 


\section{Learning Community: Jurnal Pendidikan Luar Sekolah, 3 (2), September 2019 - 43}

Fajar Nugraheni

dilakukan dengan mengukur keberhasilan program melalui penyelenggaraan ujian lokal dan pendataan terhadap lulusan peserta didik, dimana sebagian besar lulusan telah membuka usaha jasa merias pengantin sendiri, serta menjadi rekan kerja dan asisten instruktur di LKP Widya.

Setelah lulus dari kursus di LKP Widya, peserta didik tetap diberikan pembinaan dari lembaga. Melalui pembinaan ini menandakan bahwa hubungan lembaga dengan lulusan peserta didik tetap terjalin baik meskipun sudah tidak dalam masa pembelajaran. Pembinaan terhadap lulusan peserta didik dilaksanakan dengan pertemuan rutin untuk meningkatkan keterampilan lulusan dan menjalin networking dalam berkarir sebagai perias pengantin.

Terdapat berbagai faktor yang memengaruhi keberhasilan proses manajemen Program Tata Rias Pengantin Solo Putri di LKP Widya. Faktor-faktor tersebut meliputi faktor pendukung dan faktor penghambat. Faktor pendukung yang memengarui proses manajemen program ini adalah (1) sarana dan prasarana yang memadai; (2) instruktur yang berkompeten dengan dimilikinya sertifikat; (3) biaya kursus yang bersubsidi dan dapat diangsur; (4) pembinaan yang dilaksanakan secara berkelanjutan bagi lulusan peserta didik, dan (5) peluang perias pengantin cukup besar. Sedangkan, faktor penghambat yang memengarui proses manajemen program ini adalah (1) kurangnya tenaga yang menguasai IT; dan (2) peserta didik yang memiliki latar belakang beragam.

Peneliti telah memperoleh hasil penelitian terkait manajemen program kursus Tata Rias Pengantin Solo Putri di LKP Widya Semarang, yang terdiri dari: (1) proses perencanaan, (2) proses pengorganisasian, (3) proses pelaksanaan, (4) proses pengawasan, (5) proses evaluasi, dan (6) faktor pendukung dan penghambat dalam proses manajemen program kursus Tata Rias Pengantin Solo Putri di LKP Widya Semarang.

Menurut Siswanto (2011: 42), perencanaan adalah proses dasar yang digunakan untuk memilih tujuan dan menentukan cakupan pencapaiannya. Merencanakan berarti mengupayakan penggunaan sumber daya manusia (human resources), sumber daya alam (natural resources), dan sumber daya lainnya (other resources) untuk mencapai tujuan. Hal ini sejalan dengan proses perencanaan program kursus Tata Rias Pengantin Solo Putri dimana pengelola telah menetapkan tujuan yang hendak dicapai dengan diadakannya program ini, yaitu untuk memberikan pengetahuan dan keterampilan Tata Rias Pengantin Solo Putri yang sesuai dengan tradisi budaya dan dapat diterapkan sebagai sumber penghasilan.

Menurut Soetomo et al (1988) dalam oleh Sukmana \& Dian (2013: 10-14), bahwa sarana dan prasarana, serta biaya merupakan bagian dari unsur-unsur kursus. Sarana mencakup hal utama yang dibutuhkan dalam proses pembelajaran kursus, sedangkan prasarana mencakup hal yang mendukung dalam proses pembelajaran. Kemudian, dana belajar ialah uang, barang, jasa yang diperlukan untuk menjamin kelestarian kegiatan belajar pada kursus. Sumber dana kursus berasal dari pemilik, warga belajar, pihak ke-3 (swasta, pemerintah, bank, dan sebagainya), dan hasil usaha sendiri. Hal ini sejalan dengan pemenuhan sarana dan prasarana yang memadai untuk mendukung keberhasilan pencapaian tujuan program, dengan didukung pemasukan dana dari berbagai sumber sebagai pembiayaannya, yaitu kerja sama dengan mitra, unit usaha tata rias dan dana dari siswa yang dapat dibayarkan secara berangsur-angsur.

Menurut Soetomo dalam program kursus tugas utama instruktur, di antaranya: (a) menyampaikan pengetahuan dan keterampilan serta sikap swakarya yang diperlukan peserta kursus, dengan cara yang sistematis; dan (b) mendorong minat dan bakat kemampuan peserta kursus sesuai dengan tujuan belajar yang ingin dicapai. Hal ini sejalan dengan apa upaya LKP Widya untuk merekrut instruktur yang memiliki berkompeten di bidang Tata Rias Pengantin dibuktikan dengan dimilikinya sertifikat dari Lembaga Sertifikasi Kompetensi (LSK). Hal ini dilakukan agar nantinya lembaga mampu melahirkan lulusan peserta didik sebagai perias pengantin yang profesional.

Priago (2013) mengemukakan bahwa salah satu ciri-ciri kursus adalah usia warga belajar yang tidak dibatasi atau tidak perlu sama pada suatu jenis atau jenjang pendidikan. Hal ini sejalan dengan peserta didik program kursus Tata Rias Pengantin Solo Putri yang terdiri dari berbagai latar belakang, dimana perekrutannya dilakukan dengan membagikan brosur-brosur sebagai bentuk promosi dan melalui perekrutan peserta pelatihan yang telah diselenggarakan oleh dinas-dinas atau 
mitra kerja, kemudian memenuhi persyaratan pendaftaran secara administrasi.

Handoko (1992: 168) dalam Sutomo (2012: 13) menyatakan bahwa pengorganisasian merupakan suatu proses untuk merancang struktur formal, mengelompokkan dan mengatur serta membagi tugas-tugas atau pekerjaan di antara para anggota organisasi, agar tujuan organisasi dapat dicapai dengan efisien. Hal ini sejalan dengan disusunnya struktur organisasi dalam LKP Widya. Meskipun masih memiliki hubungan keluarga dan kerabat dekat, adanya struktur organisasi secara jelas dapat lebih mengefektifkan dalam mengelola lembaga. Koordinasi yang terjalin antar struktur organisasi pun bersifat informal dengan dapat tetap melakukan diskusi mengenai keberlanjuan lembaga di saat berkumpul santai tanpa harus mengadakan rapat secara formal.

Setiap komponen dalam struktur organisasi LKP Widya bertanggung jawab terhadap tugasnya masing-masing. Pembagian tugas ini disesuaikan dengan tingkat jabatannya. Selain itu, pembagian tugas juga dilakukan pada instruktur saat proses pelaksanaan program. Pembagian tugas antar instruktur dilakukan menyesuaikan materi dan keadaan, dimana asisten instruktur dapat berperan sebagai pendamping ataupun pengganti instruktur utama. Dengan adanya sistem pembagian seperti ini akan meringankan tugas setiap personal, sehingga lebih mengefektifkan lembaga dalam mencapai tujuannya. Selain itu, pembagian tugas ini perlu dilakukan agar tidak terjadi tumpang tindih aktivitas dan dapat menghambat tercapainya tujuan.Hal ini juga sejalan dengan pendapat Siswanto (2011: 75), bahwa pengorganisasian merupakan suatu pekerjaan membagi tugas, mendelegasikan otoritas, dan menetapkan aktivitas yang hendak dilakukan oleh manajer pada seluruh hierarki organisasi.

Sutarto (2014: 28) menyebutkan prinsip-prinsip atau asas yang perlu diperhatikan dalam pembentukan atau penyusunan suatu organisasi, yaitu (1) perumusan tujuan yag jelas, (2) pembagian kerja, (3) delegasi kekuasaan, (4) rentang kekuasaan, (5) tingkat pengawasan, (6) kesatuan perintah dan tanggung jawab, serta (7) koordinasi. Berdasarkan prinsip-prinsip tersebut, dengan adanya pembagian tugas dalam organisasi, maka akan terlihat pula garis komando dan delegasi kekuasaan (wewenang) dari masing-masing sumber daya manusia. Selain itu, koordinasi di antara mereka juga akan tercipta, sehingga tujuan program pun dapat segera tercapai.

Sejalan dengan penjelasan di atas, dalam struktur organisasi LKP Widya terdapat garis komando dan garis koordinasi. Dimana garis komando ini menghubungkan jabatan yang lebih atas dengan bawahannya, dimana dimaksudkan bahwa memiliki kewenangan untuk memberikan perintah yang harus dilakukan dalam proses manajemen program ini. Sedangkan, garis koordinasi menghubungkan jabatan yang tugasnya harus dijalankan bersama dengan jabatan lain.

Tahap selanjutnya dalam proses pengorganisasian program kursus Tata Rias Pengantin Solo Putri di LKP Widya adalah menjalin kerja sama dengan pihak lain. Kerja sama ini dapat mendukung kelancaran proses pelaksanaan program, sehingga membantu tercapainya tujuan yang telah direncanakan. Jalinan kerja sama LKP Widya dilakukan bersama berbagai pihak baik pemerintah maupun swasta, berupa pemberian dukungan kegiatan, sebagai narasumber kegiatan, dan permintaan jasa merias. Kerja sama LKP Widya bersama pihak mitra didasarkan adanya rasa saling membutuhkan, oleh karena itu keduanya sama-sama mendapatkan keuntungan. Sejalan dengan hasil penelitian terkait jalinan kerja sama di atas, Kamil (2007: 166) menyatakan bahwa jaringan kemitraan adalah suatu strategi bisnis yang dilakukan oleh dua pihak atau lebih dalam jangka waktu tertentu untuk meraih keuntungan bersama dengan prinsip saling membutuhkan dan membesarkan.

$$
\text { Menurut Terry (2012: 313) }
$$

pelaksanaan atau penggerakan merupakan usaha untuk menggerakkan anggota-anggota kelompok hingga mereka berkeinginan dan berusaha untuk mencapai sasaran-sasaran yang telah direncanakan. Dalam pelaksanaan ini pengelola menggerakkan instruktur agar mampu mendidik peserta didik sesuai dengan tujuan yang hendak dicapai, yaitu menjadikannya sebagai penata rias pengantin yang profesional. Begitu pula instruktur berperan besar pada saat proses pelaksanaan program kursus dengan tidak hanya memberikan materi Tata Rias Pengantin menggunakan metode dan media yang tepat, tetapi juga memberikan motivasi-motivasi yang mengarahkan peserta didik pada tujuan program ini pula. 


\section{Learning Community: Jurnal Pendidikan Luar Sekolah, 3 (2), September 2019 - 45}

Fajar Nugraheni

Akintayo dan Oghenekohwo (2006:

163) dalam Akpama, et al. (2012: 14) menyatakan bahwa dalam hal tujuan, isi, klien, metodologi dan evaluasi, pendidikan nonformal dipandang fleksibel, tidak kaku dan berbeda karena perlu diketahui pembelajar, pengetahuan, keterampilan, latihan, proses dan hasil dalam praktik. Hal tersebut juga sejalan dengan waktu pelaksanaan program yang bersifat fleksibel mengikuti kesibukan instruktur dan peserta didik. Ketidaktetapan jadwal ini dikarenakan para peserta didik dalam pendidikan nonformal memang beragam. Kemudian, tempat kegiatan program kursus dilaksanakan di ruang yang telah disediakan di gedung LKP, dimana antara teori dan praktik dijadikan satu ruang, mengingat metode pembelajaran yang menggabungkan penyampaian keduanya. Pada saat-saat tertentu, kegiatan kursus juga sesekali dilaksanakan di luar LKP dengan menyewa tempat.

Kurikulum merupakan hal yang paling wajib dimiliki oleh lembaga kursus. Dari sinilah standar yang diberikan pemerintah, sehingga setiap lembaga kursus memiliki tujuan pembelajaran yang sama walaupun dari daerah yang berbeda. Dalam dunia kursus dan pelatihan terdapat SKKNI adalah rumusan kemampuan kerja yang mencakup aspek pengetahuan, keterampilan dan/atau keahlian serta sikap kerja yang relevan dengan pelaksanaan tugas dan syarat jabatan yang ditetapkan sesuai dengan ketentuan peraturan perundang-undangan. Oleh karena itu, materi pada program kursus Tata Rias Pengantin Solo Putri disusun sesuai dengan kurikulum yang mengacu pada SKKNI. Kesesuaian materi dalam program kursus ini juga sudah sejalan dengan tujuan yang telah direncanakan LKP Widya, dimana peserta didik diberikan pengetahuan dan praktik tentang teori adat, merias, dan keterampilan sesuai tradisi budaya yang berlaku.

Daya pembeda dalam pembelajaran pendidikan nonformal adalah rentannya angka drop out dari warga belajar yang dilatarbelakangi oleh rendahnya motivasi belajar. Oleh karena itu, dalam menyampaikan materi, instruktur LKP Widya menyelipi dengan pemberian motivasi kepada para peserta didik agar selalu semangat dalam mengikuti program kursus dan kelak dapat menjadi perias pengantin yang profesional.

Menurut Soetomo et al (1988) dalam oleh Sukmana \& Dian (2013: 10-14), metode pembelajaran bertujuan agar hasil belajar dapat mencapai apa yang telah ditentukan/diharapkan, sementara itu kegiatan belajar berjalan dengan efisien. Kegiatan kursus ini dilaksanakan dengan menggabungkan metode ceramah, diskusi, kerja kelompok dan praktik, penggabungan berbagai metode dalam melaksanakan proses pembelajaran merupakan bagian tugas spesifik dari para sumber belajar. Sejalan dengan hal tersebut, dalam program ini menerapkan penggabungan metode pembelajaran, yaitu ceramah dan demonstrasi.

Menurut Rifa'i (2009: 112), media pembelajaran memegang peranan penting dalam perancangan dan penggunaan pembelajaran yang sistematis. Media dalam arti luas adalah orang, material, ataupun peristiwa yang menciptakan kondisi memungkinkan partisipan memeroleh pengetahuan, keterampilan, dan sikap. Sejalan dengan teori ini, program kursus Tata Rias Pengantin Solo Putri juga menggunakan media untuk mendukung pencapaian tujuan program. Penggunaan media ini disesuaikan dengan materi dan tempat pelaksanaan kegiatan. Media yang digunakan, yaitu patung untuk materi awal membuat cengkorongan, janur dan bunga serta perlengkapan lainnya untuk materi keterampilan, dan seorang model untuk dirias. Penggunaan media papan tulis maupun LCD proyektor juga diterapkan, namun saat kegiatan dilaksanakan di luar LKP.

Sutomo (2012: 16), pengawasan merupakan proses pengamatan dari seluruh kegiatan organisasi guna lebih menjamin bahwa semua pekerjaan yang sedang dilakukan sesuai dengan rencana yang telah ditentukan sebelumnya.Sejalan dengan teori di atas, terdapat proses pengawasan dalam program kursus Tata Rias Pengantin Solo Putri, baik secara internal maupun eksternal. Proses pengawasan secara internal dilakukan oleh lembaga terhadap kinerja instruktur dan peserta didik di setiap pertemuan. Sedangkan, proses pengawasan secara eksternal terhadap lembaga dilakukan oleh dinas dengan membuat laporan secara periodik.

Menurut Sudjana (2000: 263), evaluasi ini merupakan kegiatan penting untuk mengetahui apakah tujuan yang telah ditentukan dapat dicapai, apakah pelaksanaan program sesuai dengan rencana, dan/atau dampak apa yang telah terjadi setelah program dilaksanakan. Teori ini sejalan dengan evaluasi yang dilakukan oleh LKP Widya untuk 
mengukur tingkat keberhasilan program kursus Tata Rias Pengantin Solo Putri yang telah dilaksanakan. Pengukuran keberhasilan program kursus Tata Rias Pengantin Solo Putri di LKP Widya dilakukan dengan menyelenggarakan ujian lokal dan pendataan terhadap lulusan peserta didik, dimana sebagian besar lulusan telah membuka usaha jasa merias pengantin sendiri, serta menjadi rekan kerja dan asisten instruktur di LKP Widya.

Kamil (2007: 59) menyatakan keterkaitan antara evaluasi dan pembinaan adalah bahwa evaluasi diarahkan untuk memelihara, memperbaiki, dan mengendalikan program atau kegiatan yang seharusnya terjadi sebagaimana telah direncanakan. Menurut Sutarto (2014: 21), pembinaan secara kontinu dilaksanakan untuk mendapatkan simpati dari masyarakat, sehingga operasional pendidikan nonformal semakin efektif dan efisien demi membantu tercapainya tujuan yang telah ditetapkan. Pada hakikatnya pendidikan nonformal mempersiapkan masyarakat menyongsong tugas-tugasnya di masa depan, serta dapat membangun dirinya demi dapat ikut bertanggung jawab terhadap pembangunan masyarakat, bangsa, dan negaranya. Penjelasan di atas sejalan dengan yang dilakukan oleh LKP Widya, dimana para lulusan peserta didik tetap dibina secara berkelanjutan meskipun secara operasional program kursus telah selesai dilaksanakan. Pembinaan terhadap lulusan peserta didik dilaksanakan dengan pertemuan rutin untuk meningkatkan keterampilan lulusan dan menjalin networking dalam berkarir sebagai perias pengantin.

\section{SIMPULAN}

Simpulan dalam penelitian ini adalah proses manajemen program kursus Tata Rias Pengantin Solo Putri di LKP Widya berjalan terstruktur dan sistematis. Manajemen ini diawali dengan proses perencanaan yang meliputi penyusunan tujuan program, pengadaan sarana dan prasarana, perencanaan biaya, perekrutan instruktur, dan perekrutan peserta didik. Selanjutnya proses pengorganisasian dilakukan terhadap SDM lembaga dan instruktur, serta jalinan kerja sama. Proses pelaksanaan program berjalan sesuai yang direncanakan dimana waktu bersifat fleksibel dan menempati gedung LKP. Kesesuaian materi, metode, dan media sangat diperhatikan agar sejalan dengan tujuan. Proses pengawasan program dilakukan secara eksternal dan internal. Terakhir, proses evaluasi program meliputi pengukuran keberhasilan program dan pembinaan lulusan peserta didik secara berkelanjutan. Faktor pendukung manajemen program meliputi sarana dan prasarana yang memadai, instruktur yang berkompeten dengan dimilikinya sertifikat, biaya kursus yang bersubsidi dan dapat diangsur, pembinaan yang dilaksanakan secara berkelanjutan bagi lulusan peserta didik, peluang perias pengantin cukup besar; sedangkan faktor penghambat meliputi kurangnya tenaga yang menguasai IT dan peserta didik yang memiliki latar belakang beragam.

\section{DAFTAR PUSTAKA}

Akpama, et al. (2012). Implementation of the Millennium Development Goals in Nigeria through Non-Formal Education Curriculum. Higher Education Studies, 2(1), 11-19.

Arikunto, Suharsimi. (2006). Prosedur Penelitian Suatu Pendekatan Praktik (Edisi Revisi VI). Jakarta: Rineka Cipta.

Arikunto dan Cepi. (2014). Evaluasi Program Pendidikan Pedoman Teoritis Praktis Bagi Mahasiswa dan Praktisi Pendidikan (Edisi Kedua). Jakarta: Bumi Aksara.

Astuti, Kun S., Hadjar P., \& Yuli S. R. (2010). Pengembangan Model Evaluasi Pembelajaran Seni Budaya SMP. Jurnal Kependidikan, 40(1), 87-98.

Astuti, Maya Fuji. Hubungan Antara Kepercayaan Diri terhadap Hasil Belajar Mata Kuliah Tata Rias Pengantin Indonesia Tengah pada Mahasiswa Pendidikan Tata Rias Universitas Negeri Jakarta. Journal UNJ, 15-23.

Azzahri, Childa K., Dwi Widjanarko, \& I Made Sudana. (2017). Pengembangan Instrumen Penilaian Praktik Rias Pengantin Jogja Paes Ageng pada Mata Kuliah Rias Pengantin Jawa. Journal of Vocational and Career Education, 2(1), 22-27.

Campbell, Clifton P. (1998). Training Course/Program Evaluation: Principles 
and Practices. Journal of European Industrial Training, 22(8), 323-344.

Chairunisha, Leolita., \& Utsman. (2015). Program Pelatihan Ibu Rumah Tangga untuk Meningkatkan Kreativitas Kegiatan Usaha Pengolahan Pangan Kue Semprong (Studi Kasus pada UKM Nining di Desa Blambangan Kabupaten Magelang). Journal of Non Formal Education and Community Empowerment, 4(1), 55-62.

Daman. (2012). Monitoring dan Supervisi Pendidikan Luar Sekolah (PLS). Semarang: Universitas Negeri Semarang.

Direktorat Pembinaan Kursus dan Pelatihan. http://www.infokursus.net/perijinan. php. (Diunduh pada hari Minggu, 30 September 2018).

Fitriyah, Indah Nashichatul. (2015). Pola Pelatihan Tata Rias Pengantin Solo pada Anak Putus Sekolah di UPTD Balai Latihan Kerja (BLK). Skripsi Universitas Negeri Semarang.

Handoko, T. Hani. (2015). Manajemen (Edisi 2). Yogyakarta: BPFE.

Hanrahmawan, F. (2010). Revitalisasi Manajemen Pelatihan Tenaga Kerja (Studi Kasus pada Balai Latihan Kerja Industri Makassar). Jurnal Administrasi Publik, 1(1), 78-94.

Harian Sore Sinar Harapan. (2015). "Saatnya Lembaga Kursus Berbenah." http://scholae.co/web/read/722/saat nya.lembaga.kursus.berbenah.

Diunduh pada hari Minggu, 30 September 2018).

Hug, Annelise C. \& J. William Hug. (2010). Challenges and Opportunities for Evaluating Environmental Education Programs. Evaluation and Program Planning, 33, 159-164

Jannana, N. S., \& Yoyon Suryono. (2017). Manajemen Program Short Courses. Jurnal Akuntabilitas Manajemen Pendidikan, 5(1), 82-94.

Kamil, Mustofa. (2007). Model Pendidikan dan Pelatihan (Konsep dan Aplikasi). Bandung: Alfabeta.

Lastuti, Sri, \& Ahmad Jaedun. (2014). Evaluasi Pelaksanaan Program S1 PGSD di Unit Program Belajar Jarak Jauh UT DIY. Jurnal Kependidikan, 44(1), 39-50.

Lestari, Tiara Margi dan Nia Kusstianti. (2017). Kreasi Jilbab dan Tata Rias Pengantin Muslim Modern untuk Wajah Bulat
Ditinjau dari Unsur dan Prinsip Desain. e-Journal Unesa, 06(02), 33-40.

Laila, Linawati Zulfa I. (2013). Penyelenggaraan Program Paud Holistik Integratif di PAUD Siwi Kencana Kota Semarang. Journal of Non Formal Education and Community Empowerment, 2(1), 73-83.

Martha, Puspita. (2010). Pengantin Solo Putri \& Basahan Prosesi, Tata Rias, \& Busana. Jakarta: PT. Gramedia Pustaka Utama.

Melano, Ridhoino K. S. (2018). "Kemendikbud Sebut Masih ada Lembaga Kursus Ilegal di

Indonesia."http://pontianak.tribunnew s.com/amp/2018/03/07/

kemendikbud-sebut-masih-adalembaga-kursus-ilegal-di-indonesia.

(Diunduh pada hari Minggu, 30 September 2018).

Moleong, Lexy J. (2009). Metodologi Penelitian Kualitatif. Bandung: PT Remaja Rosdakarya.

Nasholm, Malin H., \& Tomas Blomquist. (2015). Co-creation as A Strategy for Program Management. International Journal of Managing Projects in Business, 8(1), 573.

Nisa, Sholikhatun, \& Sri Dwiyanti. (2016). Upaya Pengenalan Tata Rias Pengantin Tradisional Gagrag Kartika Rukmi pada Masyarakat di Daerah Desa Gaprang, Kanigoro, Blitar. E-Journal Unesa, 5(1), 128-136.

Nurhalim, Khomsun. (2012). Strategi Pembelajaran Pendidikan Nonformal. Semarang: Unnes Press.

Nurhandoko, Hilyar. (2009). Model Pembelajaran Kursus Komputer di Lembaga Kursus Adias Sindo Cerdas (ASC) (Studi Kasus Salah Satu Lembaga Kursus Komputer di Jalan Sindoro No. 39 Kabupaten Pemalang). Skripsi Universitas Negeri Semarang.

Priago, Ricad Neton. (2013). Pengelolaan Lembaga Kursus (LPK) Chinju dalam Menyelenggarakan Kursus Bahasa Korea di Kota Bengkulu. Skripsi Universitas Bengkulu.

Putera, Andri Donal. (2015). "Banyak Lembaga Kursus yang Malas Urus Izin Operasional."https://megapolitan.kom pas.com/read/2015/08/07/19515251 /Banyak.Lembaga.Kursus.yang.Malas.U rus.Izin.Operasional. (Diunduh pada hari Minggu, 30 September 2018). 
Putra, Pramudya D. A. \& Sudarti. (2015). Real Life Video Evaluation Dengan Sistem eLearning untuk Meningkatkan Keterampilan Berpikir Kritis Mahasiswa. Jurnal Kependidikan, 45(1), 76-89.

Rahmawati, Anisa. (2015). Faktor Faktor Minat Calon Pengantin dalam Memilih Busana Pengantin di Desa Pabelan Kecamatan Kartasura Kabupaten Sukoharjo. Skripsi Universitas Negeri Semarang.

Rifa'i, Achmad. (2009). Desain Pembelajaran Orang Dewasa. Semarang: Unnes Press.

Saerozi, Hadromi, \& Khumaedi. (2017). Pengaruh Model Pembelajaran Proyek dan Motivasi terhadap Kompetensi Praktik Pengelasan. Journal of Vocational and Career Education, 2(1), 57-62.

Sandhi, Devi Larasati. (2017). Modifikasi Tata Rias Pengantin Putri Muslim Trenggalek. e-Journal Unesa, 06(3), 7176.

Siswanto. (2011). Pengantar Manajemen. Jakarta: PT Bumi Aksara. (2013). Membangun Motivasi Belajar Pendidikan Nonformal. Semarang: FIP UNNES.

Sudjana, Djudju. (2008). Evaluasi Program Pendidikan Luar Sekolah. Bandung: PT Remaja Rosdakarya.

(2000). Manajemen Program Pendidikan untuk Pendidikan Luar Sekolah dan Pengembangan Sumber Daya Manusia. Bandung: Falah Production.

Sufa, Faila. (2017). Manajemen Program Kursus Tata Kecantikan Rambut di LKP Zeta di Kabupaten Demak. Skripsi Universitas Negeri Semarang.

Sugiyono. (2012). Metode Penelitian Pendidikan Pendekatan Kuantitatif, Kualitatif, dan R\&D. Bandung: Alfabeta. (2015). Memahami penelitian Kualitatif. Bandung: Alfabeta. . (2017). Metode Penelitian Kuantitatif, Kualitatif, dan R\&D. Bandung: Alfabeta.

Sujanto, Alex. (2015). Course Management Model Development Based on World of Business and Industries (WBI) on Life Skills Education Courses and Training Institutions (LSE-CTI) (FOG-C Management Model). UNISRI Solo, 5169.
Sukmana, Cucu \& Dian Dwilestari. (2013). Analisis Mutu Kursus. Jakarta: Pusat Data dan Statistik Pendidikan, Kemdikbud.

Sulistiyo, Ari. (2016). Manajemen Pembelajaran Kursus Bahasa Inggris pada Lembaga International Language Programs Semarang.Skripsi Universitas Negeri Semarang.

Suryabrata, Sumadi. (2011). Metodologi Penelitian. Jakarta: PT Rajagrafindo Persada.

Sutarto, Joko. (2013). Manajemen Pelatihan. Yogyakarta: Deepublish.

(2014). Manajemen Pendidikan Nonformal. Semarang: Unnes.

Sutomo. (2012). Manajemen Sekolah. Semarang: Unnes Press.

Suyitno, Imam, dkk. (2016). Teknik Pembelajaran Observasi Lingkungan Berbasis Kearifan Lokal. Jurnal Kependidikan, 46(1), 14-28.

Takdira, A. (2012). Peningkatan Kualitas Layanan Program Kursus di Pusat Kegiatan Belajar Masyarakat (PKBM) Citra Ilmu Kabupaten Semarang Jawa Tengah. Journal of Non Formal Education and Community Empowerment, 1(1), 14-23.

Terry, George R. (2012). Asas-asa Menejemen. Terjemahan Winardi. Bandung: P.T. Alumni.

Usman, Husaini. (2013). Manajemen: Teori, Praktik, dan Riset Pendidikan (Edisi 4). Jakarta: Bumi Aksara.

Wahyudin, Dinn. (2016). Manajemen Kurikulum dalam Pendidikan Profesi Guru (Studi Kasus di Universitas Pendidikan Indonesia). Jurnal Kependidikan, 46(2), 259-270.

Widiasih, E., \& Tri Suminar. (2015). Monitoring dan Evaluasi Program Pelatihan Batik Brebesan (Studi di Mitra Batik Desa Bentar, Kecamatan Salem, Kabupaten Brebes). Journal of Non Formal Education and Community Empowerment, 4(1), 41-48.

Widoyoko, S. Eko P. (2016). Evaluasi Program Pembelajaran Panduan Praktis bagi Pendidik dan Calon Pendidik. Yogyakarta: Pustaka Pelajar.

Wikanah, Does I. T. (2015). Pengelolaan Pembelajaran Berbasis Kualitas di Lembaga Kursus dan Pelatihan Magistra Utama Kota Semarang. 
Learning Community: Jurnal Pendidikan Luar Sekolah, 3 (2), September 2019 - 49

Fajar Nugraheni

Journal of Nonformal Education, 1(1), Wulandari, Yunika Niken. (2009). Peranan 43-49.

Wulandari, N. A. D., \& Ilyas. (2015). Manajemen Penyelenggaraan Pelatihan Otomotif dalam Mempersiapkan Warga Belajar Memasuki Dunia Kerja di BLKI Semarang. Journal of Non Formal Education and Community Empowerment, 4(2), 107-114. Juru Rias Pengantin dalam Melestarikan Tata Rias dan Busana Pengantin Adat Solo Putri di Kabupaten Temanggung. Skripsi Universitas Negeri Semarang.

Zulfida, Ida, Akhmad F., Ernan R., Yusman S. (2015). Kinerja Program Nasional Pemberdayaan Masyarakat Mandiri Perdesaan di Kabupaten Bandung. Mimbar, 31(2), 307-318. 